\title{
Effect of cognitive rehabilitation training on promotion of emotion regulation in women with postpartum depression
}

\author{
Masoud Sayadi ${ }^{1,2}$, Zahra Eftekhar Saadi ${ }^{2}$, Behnam Makvandi ${ }^{2}$, Fariba Hafezi ${ }^{2}$ \\ 1-Department of Psychology, Khuzestan Science and Research Branch, Islamic Azad University, Ahvaz, Iran. \\ 2- Department of Psychology, Ahvaz Branch, Islamic Azad University, Ahvaz, Iran. \\ Corresponding Author: Zahra Eftekhar Saadi, Department of Psychology, Ahvaz Branch, Islamic Azad \\ University, Ahvaz, Iran. Email: eftekharsaadi@yahoo.com \\ Masoud Sayadi ORCID: 0000-0002-9850-0462 \\ Zahra Eftekhar Saadi ORCID: 0000-0002-9850-0462 \\ Behnam Makvandi ORCID: 0000-0002-6285-3805 \\ Fariba Hafezi ORCID: 0000-0002-7453-8327
}

Received: 05/03/2019

Accepted: 22/05/2019

\section{Abstract}

Introduction: Depression is one of the most common postpartum disturbances. Also, women with postpartum depression have emotional regulation problems.

Aim: The aim of this study was to investigate the effect of cognitive rehabilitation training on emotional regulation of women with postpartum depression.

Method: The research method was based on semi-experimental, pre-test, post-test and follow-up in relation to the control group. The sample consisted of 40 women with postpartum depression who were selected based on available simple random sampling. The groups were matched in terms of age, education, severity of depression, etc. Both groups were evaluated in the stages of pretest and post-test by emotional regulation questionnaire (Garnovskii,2001). For analysis of data, covariance analysis and SPSS19 software was used.

Results: The data analysis indicated that cognitive rehabilitation in the experimental group compared with the control group had a significant change in the emotional regulation scores, and this effect has continued during the follow-up phase $(\mathrm{P}<0.001)$.

Conclusion: According to the findings of this study, cognitive rehabilitation therapy can be used to treatment of emotional regulation in women with postpartum depression

Keywords: Cognitive rehabilitation, Emotional regulation, Women, Postpartum depression

How to cite this article : Sayadi M, Eftekhar Saadi Z, Makvandi B, Hafezi F. Effect of cognitive rehabilitation training on promotion of emotion regulationin in women with postpartum depression. Shenakht Journal of Psychology and Psychiatry. 2019; 6 (3): 31-45 .URL: http://shenakht.muk.ac.ir/article-1-506-fa.pdf

Copyright (C) 2018 the Author (s). Published by Kurdistan University of Medical Sciences. This is an open access article distributed under the terms of the Creative Commons Attribution-Non Commercial License 4.0 (CCBY-NC), where it is permissible to download, share, remix, transform, and buildup the work provided it is properly cited. The work cannot be used commercially without permission from the journal. 


\section{بررسى اثربخشى توانبخشى شناختى بر تنظيم هيجانى زنان مبتلا به

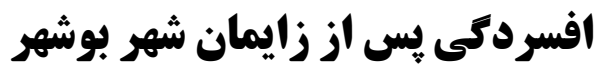

مسعود صيادى '9r، زهرا افتخار صعادى'، بهنام مكوندى'، فريبا حافظى' ا. كروه روانشناسى، يرديس علوم و تحقيقات خوزستان، دانشكاه آزاد اسلامى، اهو از، ايران.

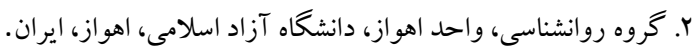

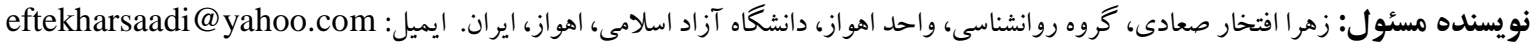

مقدمه: افسردگى يكى از اختلالات شايع دوره بِ از زايمان است همجنين، زنان مبتلا به افسردگى بِ از زايمان داراى مشكلاتى در تنظيم هيجانى هستند. هدف: يُزوهش حاضر با هدف بررسى اثربخشى توانبخشى شناختى بر تنظيم هيجانى زنان مبتلا به افسردگى بس از زايمان انجام

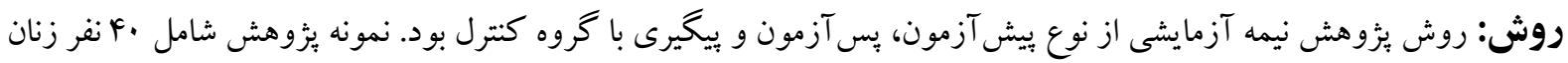

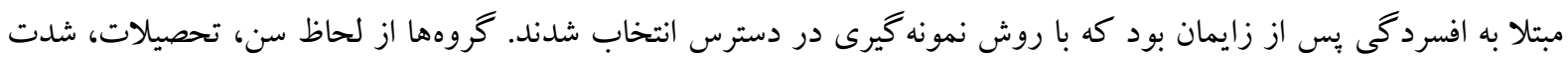

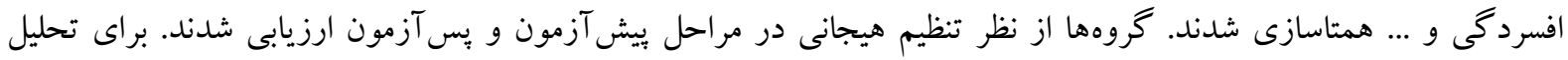
دادهها از روش تحليل كواريانس جند متغيرى و نرم افزار 19 SPSS استفاده شد. يافتها: نتايج حاصل از تحليل دادهها نشان داد، توانبخشى شناختى در گروه آزمايش در مقايسه با گروه كنترل باعث تغيير

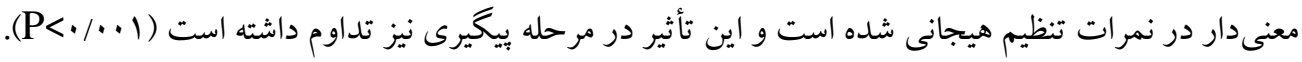
نتيجه كيرى: بنابراين مى توان نتيجه گرفت كه توانبخشى شناختى مى تو اند در تنظيم هيجانى افراد مبتلا به افسردگى بِ از زايمان مورد استفاده قرار گيرد. كليد وازهها: توانبخشى شناختى، تنظيم هيجانى، زنان، افسردگى بس از زايمان 


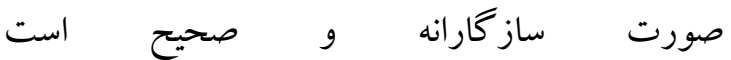
مقدمه

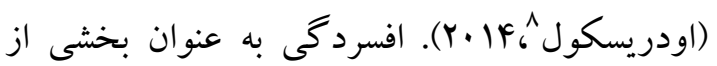

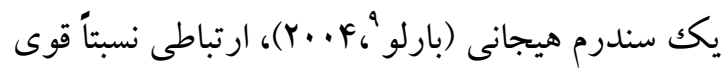

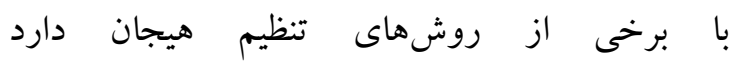

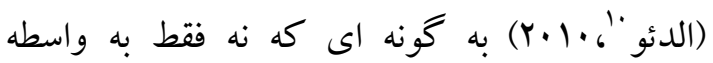
تجربهُ هيجان غيرعادى تعيين مىشود، بلكه به واسطة

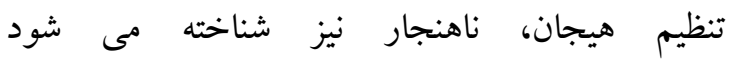

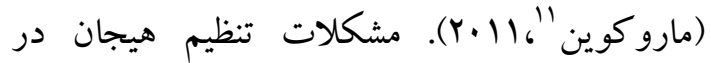
مواردى همجون اختلالهاى خلقى و اضطرابى، به حدى برجسته است كه اين اختلالات اساساً بر پايه

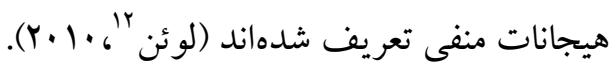

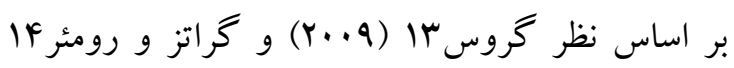
و و (Y.F) بيرونى كه مسئول ثبت ارزيابى و اصلاح واكنشهاى هيجانى هستند و بهخصوص الخوهاى موقتى در جهت رسيدن به هدف تلقى مىشوند تعريف مىشود. راهبردهاى نه كانه تنظيم شناختى هيجان را به دو نوع راهبرد مجزا تقسيم كردهاند: راهبردهاى انطباقى يا ساز گارانه؛ شامل تمر كز مجدد مثبت، ارزيابى مجدد مثبت، ديد كاه بذيرى، تمركز مجدد بر برنامهريزى و

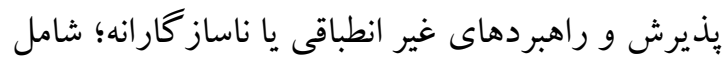
خود سرزنش گرى، سرزنش ديخرى، نشخوار فكرى و و

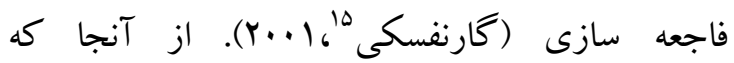

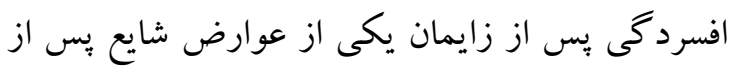

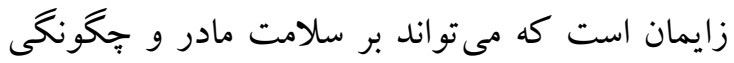
ارتباط وى با نوزاد و خانواده تأثير منفى بـذاردارد

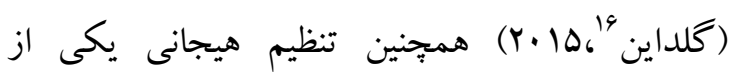

\footnotetext{
8. O'Driscoll

${ }^{9}$. Barlow

${ }^{10}$. Aldao

${ }_{11}$. Marroquin

12 . Sloan

13 . Gross JJ

14. Gratz KL, Roemer L

${ }^{15}$. Garnefski

16 . Goldin
}

يكى از شايعترين اختلالات روانى بـ بس از زايمان،

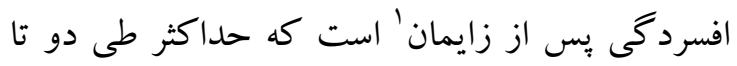
شش هفته بعد از زايمان شروع مىشود و علائم آن

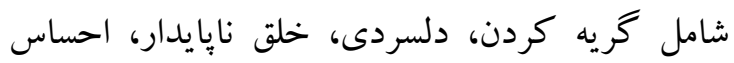
عدم كفايت و ناتوانى در نقش مادرى است (فريتز 'ّ و

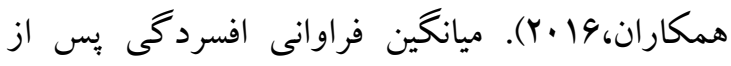
زايمان حدود سا درصد است، اما برخى مطالعات در

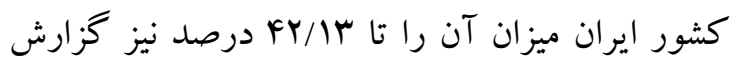

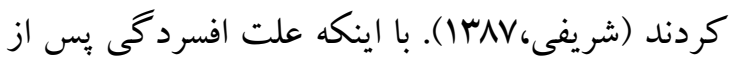
زايمان مشخص نيست، اما اين اختلال يكك اختلال جندعاملى است كه از عوامل مهم آن مىتوان به تغييرات هورمونى بس از زايمان، تطبيق روانشناختى لازم پِ از تولد، كمبود خواب و مراقبت از نوزاد

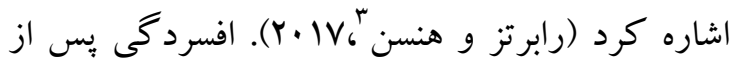
زايمان كيفيت ارتباط عاطفى مادر و كودكى را تغيير مى دهد و علاوه بر آن روابط درون خانواده، بهداشت روان خانواده و جنبه هاى مختلف رابطه با همسر را تحت تأثير قرار مىدهد و مشكلات متعددى را به

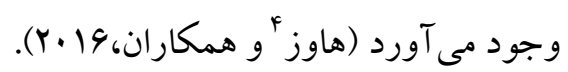
تعدادى از محققان به نقش مهم الكوهاى ناساز گارانه تنظيم هيجانى بهعنوان عاملى ميانجى در ابتلاء فرد به

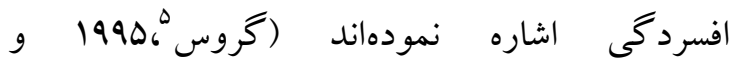

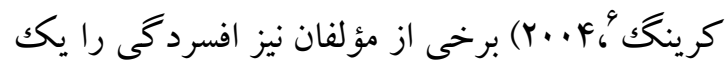
اختلال ناشى از تنظيم هيجان مىدانند و آن را بيامد

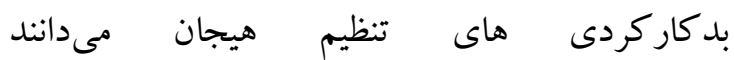

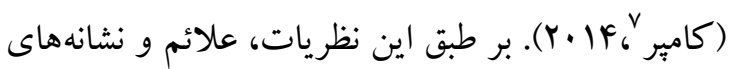
افسردگى بيامد نقص فرد در تنظيم هيجانات خود به

\footnotetext{
. Postpartum Depression

. Freitas

3 . Roberts TA, Hansen S

4. Hawes

${ }^{5}$. Gross

6 . Kring

7. Compare
} 
تنظيم شناختى هيجان مىتواند علائم اختلال افسردگى

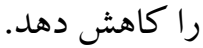
توانبخشى شناختى به مجموعه آموزشهايى اطلاق مىشود كه مبتنى بر ادغام يافتهاى علوم اعصاب شناختى و فناورى اطلاعات با تكيه بر اصل انعطافيذيرى مغز و غال با به شكل بازى است (كا ₹لياردى شيوههاست كه روشى جهت باز گرداندن ظرفيتهاى شناختى ازدسترفته است كه توسط تمرينات و ارائه محرككهاى هدفمند صورت مىيذيرد و هدف آن بهبود عملكرد فرد در اجراى فعاليتها از طريق بهبود همدي ادراك، توجه، حافظه، حل مسئله، هوشيارى،

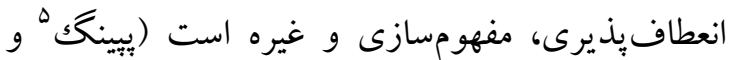

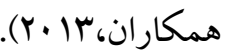
رويكردى كه در اجراى آموزش توانبخشى شناختى

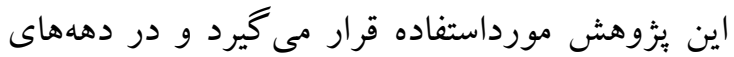
اخير نيز تمايل براى استفاده از آن افزايشيافته، استفاده

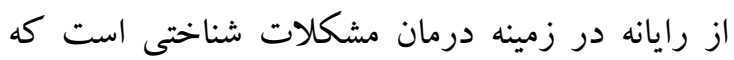
باعث گسترش برنامههاى آموزش شناختى مبتنى بر رايانه شده است. اين برنامها قابليت تنظيم سطح دشوارى تكليف از ساده به مشكل بر اساس تفاوتهاى

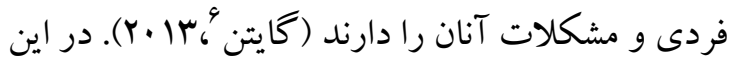
اين روش درمانگر اطلاعات حاصل از ارزيابى جلسات را در نظر گرفته و مبتنى بر آن تكاليفى براى تقويت

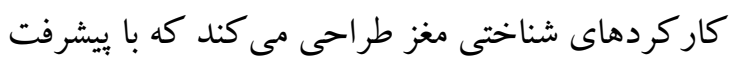
بيمارى، درجه دشوارى تكليف را افزايش مىدهد

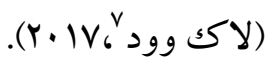

يثزوهشهاى نسبتاً زيادى درباره تأثير آموزش توانبخشى شناختى بر برخى اختلالات انجام شده، اما
عوامل مهم و اساسى بهزيستى و كنش ورى موفق بوده و نقشى مهم در ساز گارى با وقايع استرسزاى زند دارد و مهارتى مهم در مواجهه با مشكلات فردى و

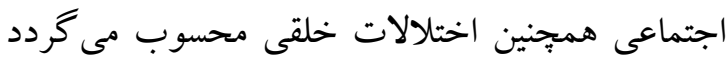
(كافتسيوس' و همكاران،بال·Y)، توجه به فرايندهاى شناختى و هيجان در درمان اين اختلال از اهميت و ضرورت فراوانى برخوردار است. در اين راستا، يكى از رويكردهاى درمانى كه مىتواند در زمينه درمان افسردگى پس از زايمان مورد استفاده قرار بحيرد آموزش توانبخشى شناختى ' است. اثربخشى توانبخشى شناختى در يزوهشهاى قبلى

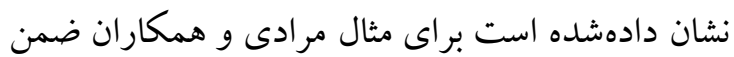
يزوهشى به اين نتيجه رسيدند كه از ميان راهبردهاى تنظيم شناختى هيجان فاجعه انگارى، سرزنش ديخرى،

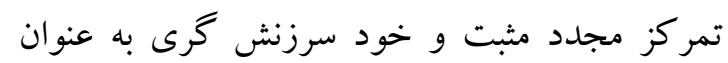
سازهاى مرتبط با علائم افسردگى در زنان متأهل است و اين متغيرها را به عنوان عواملى مهم در ارتباط با بيشخيرى و درمان افسردگى مورد بررسى قرار دادند

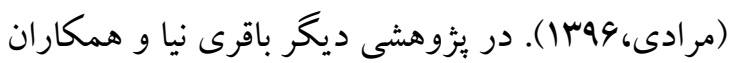
كزارش كردند كه درمان شناختى رفتارى و درمان حضور ذهن تأثير معنىدار در بهبود تنظيم هيجانى افراد

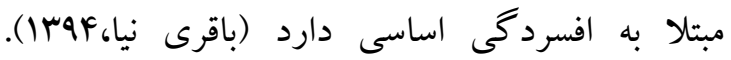
همجِين شيرى و همكاران در يُزوهشى به بررسى اثربخشى توانبخشى شناختى بر بهبود تشخيص حالات

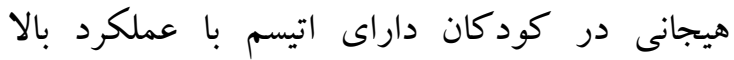
يرداختند. اندازه اثر نشان داد آموزش توانبخشى شناختى بر تشخيص حالات هيجانى مؤثر بوده است

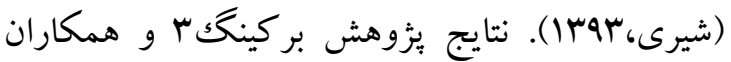
ديخر (T/ ·Y)، نشان داد اصلاح راهبردهاى ناساز گارانه 
بالينى، داشتن حداقل تحصيلات دييلم كه از طريق بررسى برونده يزشكى، برسشنامه تشخيص افسردگى و

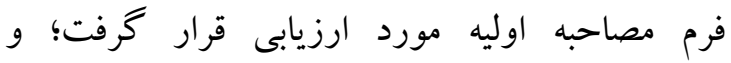
ملاككهاى خروج از مطالعه شامل: ابتلاى همزمان به مرديه

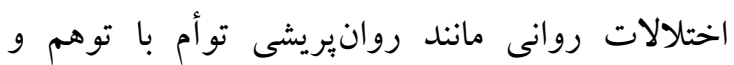
هذيان، اختلال شناختى مغزى، دوقطبى شديد و اختلال شخصيت همجنين بيمارىهاى جسمى خاص از قبيل

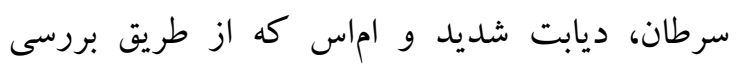
يرونده يزشكى مورد ارزيابى قرار گرفت، غيبت دو

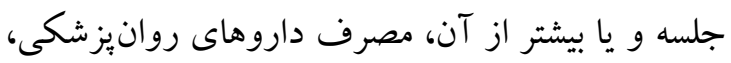

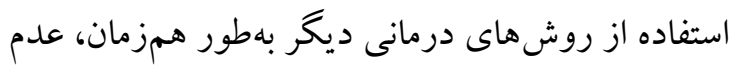

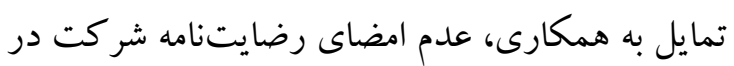
يثزوهش و يرسشنامههايى بود كه ناقص تكميلشده بود.

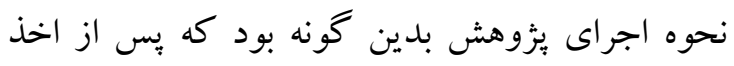

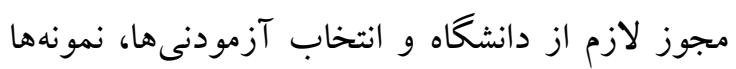

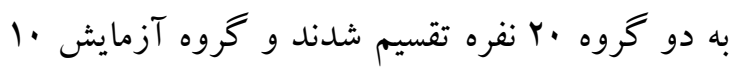
جلسه FO دقيقهاى (هفتهاى دو جلسه) بهصورت انفر ادى آموزش شناختى دريافت كرد و كروه كنترل آموزشى دريافت نكرد. محتوى مداخله توسط سولبر گك و ماتير' طراحى و توسط عباسى و همكاران مورد (Y...l) استفاده و تائيد قرار كرفت كه محتوى به تفكيك ونى

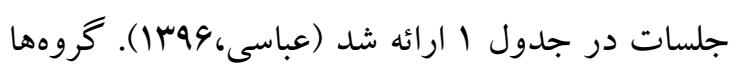
از نظر متغيرهاى يُزوهش در مراحل بيش آزمون و و بِ آزمون به كمكك ابزارهاى زير مورد ارزيابى قرار كرفتند. دادهها در دو سطح توصيفى و استنباطى به

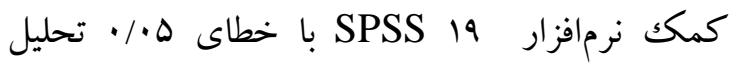
شدند. در سطح توصيفى براى توصيف توزيع متغيرها از

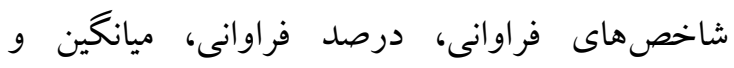
انحراف معيار و در سطح استنباطى براى آزمون فرضهاى آمارى از تحليل كوواريانس جندمتغيرى

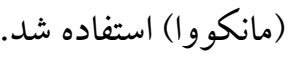

يخوهشهاى كمترى درباره تأثير آموزش توانبخشى شناختى بر تنظيم هيجانى انجام شده و حتى كاهى نتايج آنها نيز متناقض مىباشند، از طرفى با توجه به تئورى

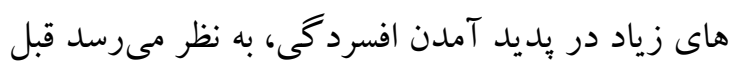

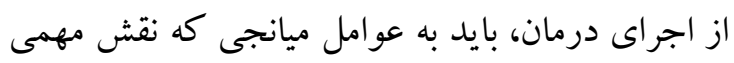
در ابتلاى فرد به افسردگى دارند، توجه شود بنابراين

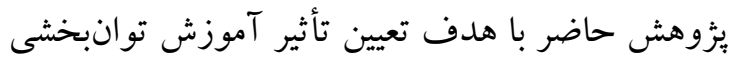

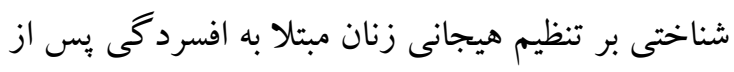

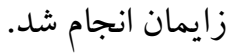

روش

مطالعه حاضر نيمه تجربى با طرح ييش آزمون و و پس آزمون و بيخيرى با گروههاى آزمايش و كنترل

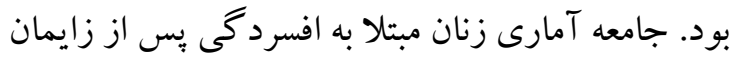

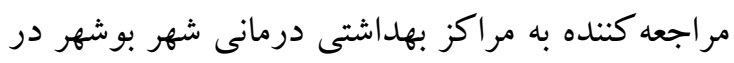

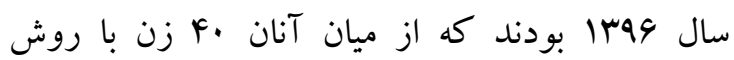

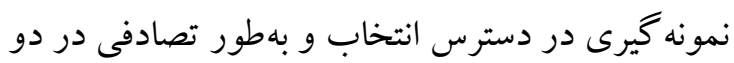

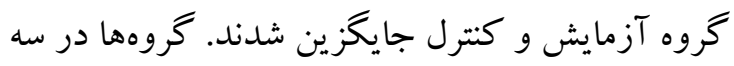

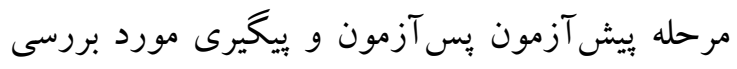

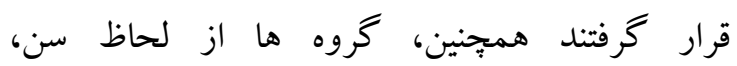

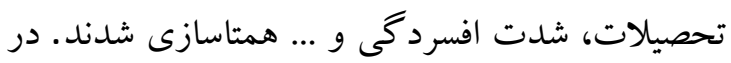
روش نمونه گيرى در دسترس بس از هماهنكى با بال مسئولان مراكز بهداشتى درمانى از ميان زنان مبتلا به

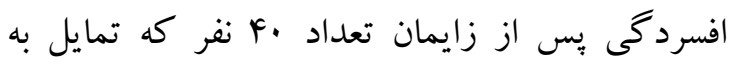
شركت در دوره آموزشى را داشتند، انتخاب شدند و ولمش

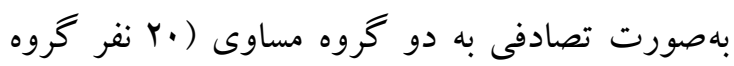

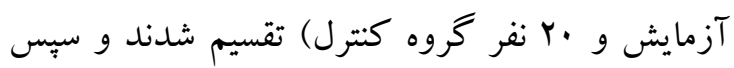
بهصورت تصادفى يكى از گروهها بهعنوان گرووه

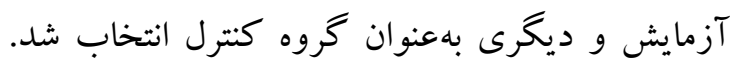
مهم ترين ملاككهاى ورود به مطالعه شامل كذشتن حداقل دو هفته از زايمان، داشتن سن •r تا هr سال، داشتن افسردگى پِ از زايمان بر اساس مصاحبه 
سؤالهاى آن در مقياس ليكرت از صفر تا سه نمره

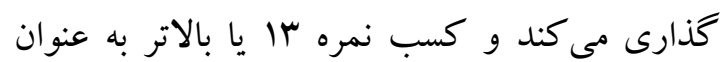

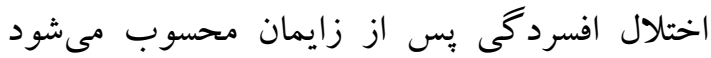
(YN) بُوهشهاى خارج و داخل كشور تأييدشده است

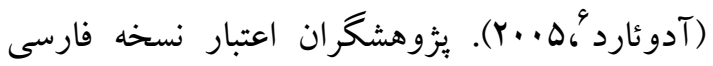
آزمون مذكور را از طريق بازآزمايى (^/•) و آلفاى

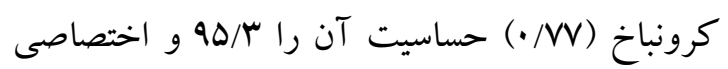

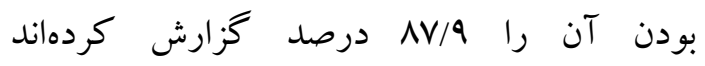
(نظرى، (نANF). شايان ذكر است كه در بزوهش حاضر از اين مقياس در كنار انجام مصاحبه بالينى جهت تعيين افسردگى بس از زايمان شركت كنند كان بيش از انجام مداخله استفاده شده است. مقياس تنظيم شناختى هيجان! '؛ مقياس تنظيم شناختى

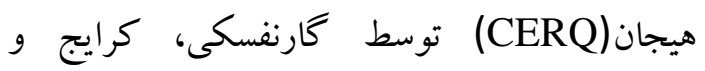

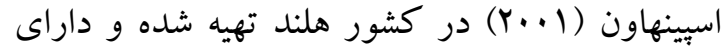
دو نسخه انكليسى و هلندى است. اين برسشنامه يك ابزار خود كزارشى است و داراى وه ماده است

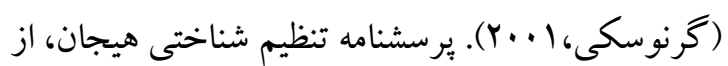
9 خرده مقياس و وس ماده تشكيل شده است. ينج خرده مقياس اين يرسشنامه راهبردهاى مثبت تنظيم شناختى لحردي

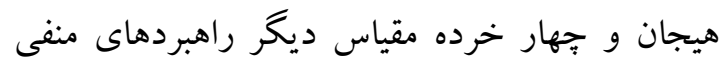
تنظيم شناختى هيجان هستند .الف) راهبردهاى مثبت تنظيم شناختى هيجان از راهبردهاى مقابلهاى بهنجار محسوب مىشوند كه عبارتاند از ا. يذيرش، r. توجه

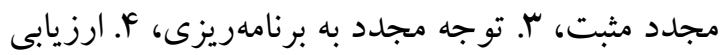
مجدد مثبت، ه. اتخاذ ديدگاه .ب) راهبردهاى منفى تنظيم شناختى هيجان از راهبردهاى مقابلهاى نابهنجار محسوب مىشوند كه عبارتاند از :ا. سرزنش خود

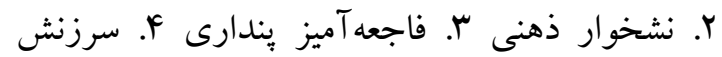

يرسشنامه ويثكىهاى جمعيت شناختى: اين برسشنامه توسط محقق يا محققين ديكر و به منظور تعيين مشخصات جمعيت شناسى آزمودنى از جمله سن، وضعيت تأهل، ميزان تحصيلات و نيز بررسى ملاككهاى حذف و متغيرهاى كنترل (معيارهاى ورود و خروج) تهيه و استفاده شد. اين آزمون فقط جهت غربال استفاده شده است و براى سنجش متغيرهاى ذيل

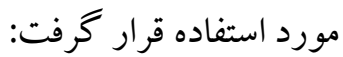
-وضعيت اشتغال (شاغل/خانه دار) - رضايت از جنسيت كودك (دارد/ندارد) -نوع زايمان (خواسته /ناخو استه) -روش زايمان (طبيعى /سزارين) نوع تغذيه كودك (شيرخشك /طبيعى) و ساير معيارهاى ورود و خروج يزوهش مقياس افسردكى بـ از زايمان ادينبركى': اين

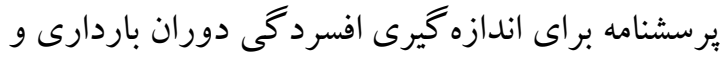

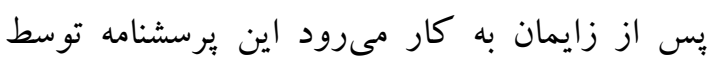

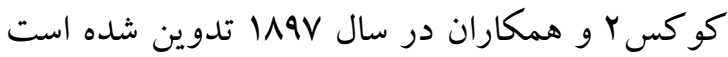

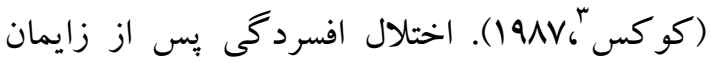

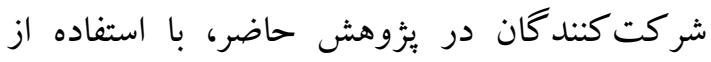

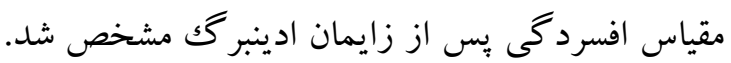
مقياس افسردگى پس از زايمان ادينبرگك، توسط

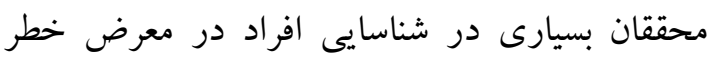
براى بيشخيرى از افسردگى بس از زايمان و ويا تعبين شدت اين اختلال قبل از ارائهُ برنامهٔ مداخله اي استفاده

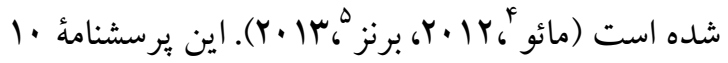
سؤالى حالات روان شناختى مادر را بررسى و

1 . Edinburgh Postnatal Depression Scale

2 -Cox JL

3. Cox

4. Mao

5. Burns 


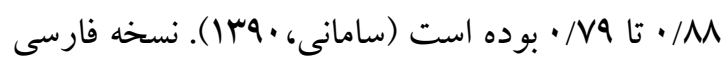

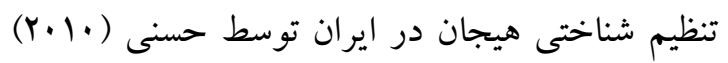

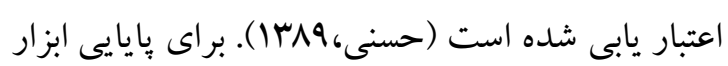

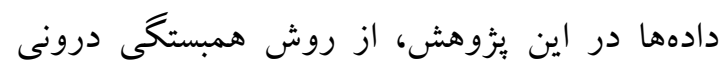

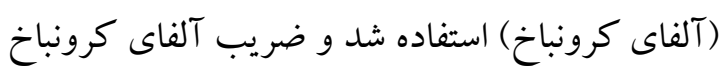
براى هر كدام از زير مقياسهاى راهبردهاى تنظيم

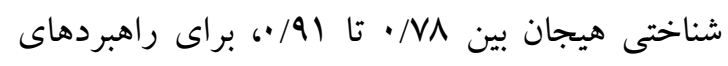
مثبت تنظيم شناختى هيجان 149/ • و راهبردهاى منفى تنظيم شناختى هيجان ه// • به دست آمد. برنامة توانبخشى - شناختى كه در اين مطالعه مورد استفاده قرار گرفت، مبتنى بر مدل سلسله مراتبى

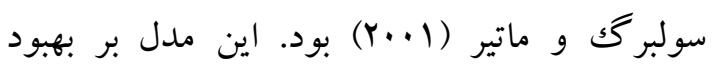

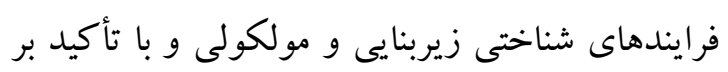
بهبود كار كردهاى اجرايى تهيه گرديده است. محتو اي جلسات درمانى بهصورت خلاصه به شرح زير

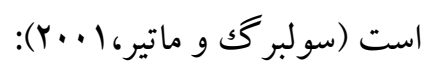

ديخران. دامنه نمرات هر سؤال مقياس از ا (تقريباً

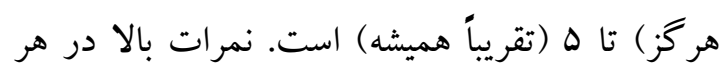
خرده مقياس، بيانكر ميزان استفاده بيشتر از راهبرد

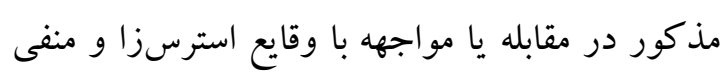

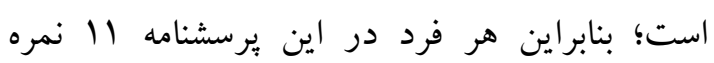
جداكانه مىتواند دريافت كند. همجينين از جمع كل

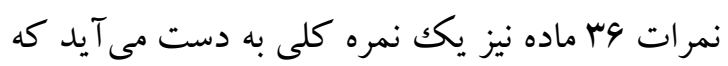
بيانكر استفاده از راهبردهاى تنظيم شناختى هيجان است و مىتواند در دامنه ايى از وس تا • •1 قرار بخيرد. در بررسى مشخصات روانسنجى آزمون، گارنفسكى

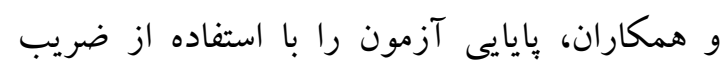

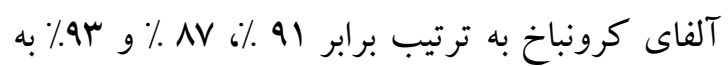

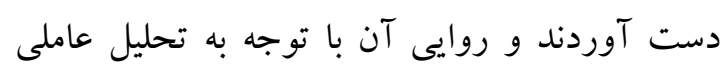

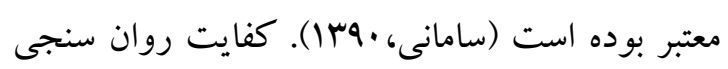
يرسشنامه تنظيم شناختى هيجان در ايران توسط سامانى و صادقى مطلوب گزارش شده و ضريب آلفا براى اين

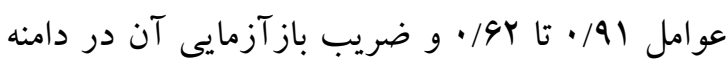

جدول ا محتوى مداخله توانبخشى شناختى به تفكيكى جلسات

\begin{tabular}{|c|c|}
\hline محتوى & جلسات \\
\hline آشنايى و برقرارى اتحاد درمانى، آشنايى با روش ها و تمرينهاى شناختى و اندازه گيرى خط يايه كار كردهاى شناختى & اول \\
\hline 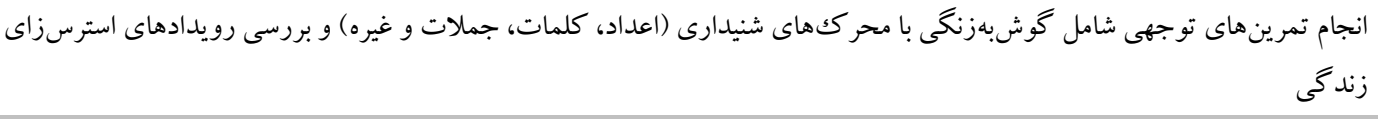 & دوم \\
\hline \multirow{2}{*}{ شدها و انجه كاربرك توضيحات تمرينهاى توجهى شامل شفظ شناختى، آموزش مهارت عناصر توجهى (خواندن متن و ييدا كردن حروف و كلمات از قبل تعيين } & سوم \\
\hline & \\
\hline آموزش تمرين هاى توجهى ديدارى و شنيدارى و تمرينهاى حافظه (توجه انتخابى و يردازش توجهى) & جهارم \\
\hline آموزش تمرين هاى تغيير توجه، دركك مطلب و بسط شناختى & هنجم \\
\hline \multirow{3}{*}{ تقبل تعيين شده تمرين هاى رعايت نظم نزولى و صعودى جهت حفظ توجه و خواندن براى دركى مطلب و جستجوى همزمان حروف يا كلمات از } & ششم \\
\hline & \\
\hline & هفتم \\
\hline بهبود حافظه كلامى و تصويرى، سازماندهى كلامى و ساخت تداعىهاى زوجى & هشتم \\
\hline ن طرح مربوط به يكك تكليف ساده، طبقهبندى، تمايز قائل شدن، حل مسئله و خود & نهم \\
\hline آموزش و اجر اى تمرين هاى حافظه بهويزه حافظه حركتى و تمرين هاى شناختى توجه، جمعبندى و خلاصه كردن مطالب جلسات قبل & دهم \\
\hline
\end{tabular}


و 11 نفر سزارين (.\%ه ) و در گروه كنترل سا نفر

يافتهها طبيعى (

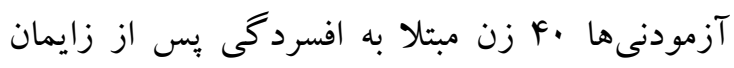

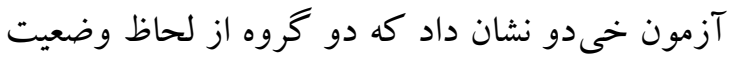

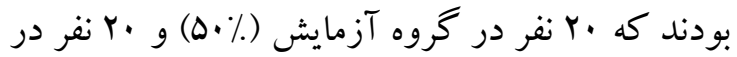

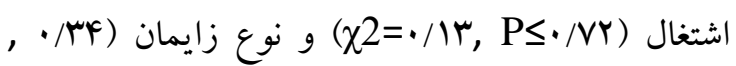

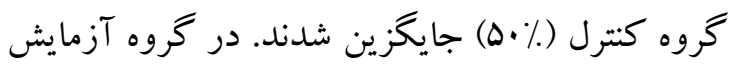
(X2=1/9YPS

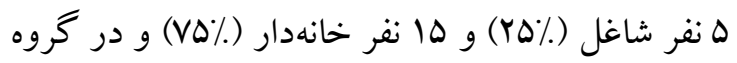

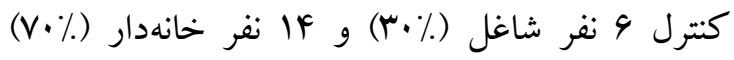
بودند. همجنين از لحاظ نوع زايمان 9 نفر طبيعى (F\%)

جدول r ميانكين و انحر اف معيار متغيرهاى يزوهش به تفكيك كروهها در مراحل بيش آزمون و پِس آزمون يس آزمون ييشآزمون

\begin{tabular}{|c|c|c|c|c|c|}
\hline انحر اف معيار & ميانگين & انحر اف معيار & ميانگين & كروهها & متغير \\
\hline $11 / 4$. & $|r F /|$. & $11 / \cdot 9$ & IYF/Y. & كروه آزمايش & \multirow[t]{2}{*}{ تنظيم هيجان } \\
\hline $9 / 90$ & $11 N / \Delta \Delta$ & $19 / .$. & $110 / V \Delta$ & گروه كنترل & \\
\hline
\end{tabular}

همجنين نمودار ستونى مقايسه ميانگين نمرات متغيرهاى

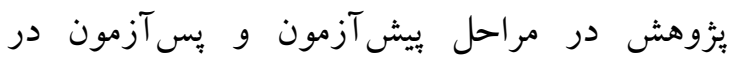
كروههاى آزمايش و كنترل در نمودار الروائه شد.
در جدول ب، نتايج ميانخين و انحراف معيار تنظيم

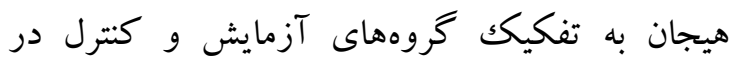
مراحل بيش آزمون و پِّ آزمون قابل مشاهده است.

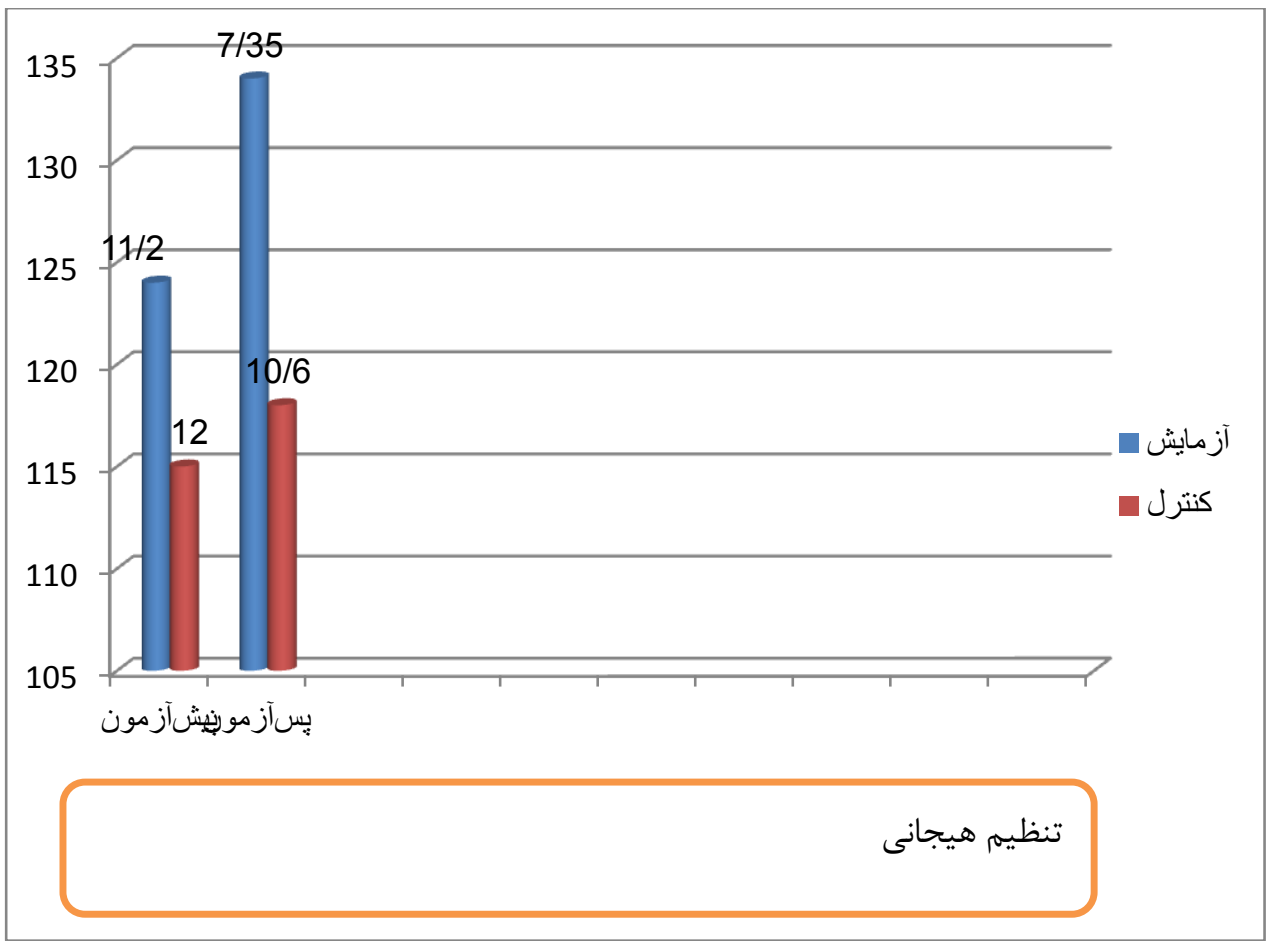

نمودار ا نمودار ستونى مقايسه ميانكين نمرات متغيرهاى ثزوهش در مراحل ارزيابى 
آزمون كرويت بارتلت معنادار بود كه اين يافته حاكى از آن است كه همبستخى كافى بين متغيرهاى وابسته وجود دارد؛ بنابراين شرايط استفاده از تحليل كوواريانس جندمتغيرى وجود دارد. براى بررسى تأثير آموزش توانبخشى شناختى بر ارتقاء تنظيم شناختى

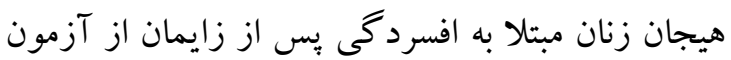

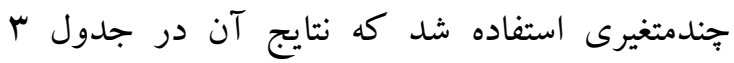

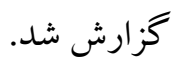
نتايج آزمون لون نشان داد كه فرض برابرى خطاى

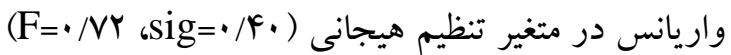
تائيد مى گردد نتايج تحليل كوواريانس در جداول ذئيل ذئل

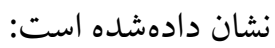

در نمودار 1 مقايسه ميانگين نمرات متغيرهاى مفهومسازى، انعطاف يذيرى ذهنى، آغاز گرى و طرح يذيرى، بازدارى و حافظه شنيدارى گروههاى آزمايش

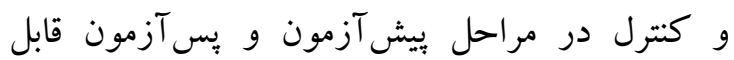
مشاهده است. بيش از انجام تحليل دادهها با روش تحليل كوواريانس هندمتغيرى، بيش فرضهاى آن بررسى شد. نتايج آزمون كولموگروف - اسميرنوف براى هيج يكك از متغيرهاى بثزوهش معنادار نبود كه اين يافته حاكى از آن است كه فرض نرمال بودن برقرار است. همجنين نتايج آزمون M باكس و آزمون لوين

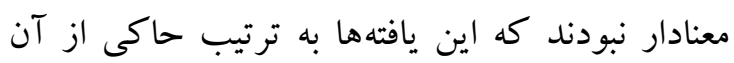

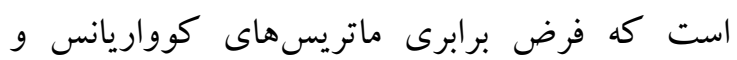
فرض برابرى واريانسها برقرار است. علاوه بر آن نتايج

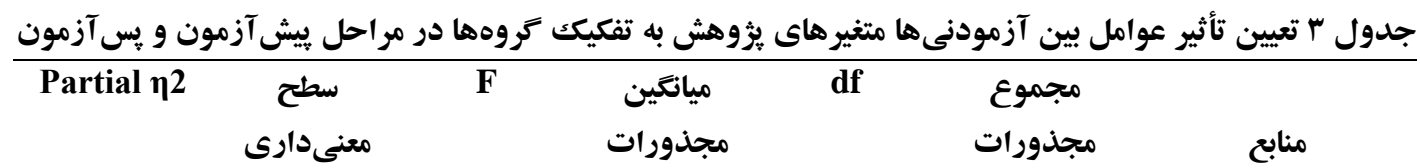

\begin{tabular}{|c|c|c|c|c|c|c|}
\hline . $19 \Delta r$ & $\cdot / \cdot \cdot 1$ & MF/AFG & $1 \wedge 94 / 0 . \Delta$ & r & rVar/.1. & مدل تصحيحشده \\
\hline - NrG &.$/ \cdot 1$ & $91 / .99$ & $\Delta M T V / r A T$ & 1 & DrTV/rKF & عرض از مبدأ \\
\hline$\cdot / 4 \cdot 9$ &.$/ \cdot 1$ & $r \Delta / Y G T$ & $\mid r V F / q \wedge \Delta$ & 1 & $\mid r V F / q \wedge \Delta$ & بيش آزمون \\
\hline \multirow[t]{3}{*}{ - /FYF } & $\cdot / \cdot \cdot 1$ & $r V / r \wedge q$ & $\mid F \wedge \Delta / Y \cdot V$ & 1 & $\mid F \wedge \Delta / Y \cdot V$ & كروه \\
\hline & & & $\Delta F / F Y G$ & rV & $r \cdot 1 r / V 90$ & خطا \\
\hline & & & & f. & gFfirv/.. & كل \\
\hline
\end{tabular}

FY/F درصد واريانس تنظيم هيجانى توسط توان بخشى شناختى تبيين مى گردد.
نتايج نشان داد يس از تعديل اثر بيش آزمون،

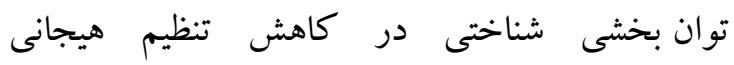
آزمودنىها معنىدار بود. ضريب ها نشان مىدهد كه

\begin{tabular}{|c|c|c|c|c|c|c|c|}
\hline \multirow[t]{2}{*}{ Partial $\eta 2$} & \multicolumn{2}{|c|}{ حدود اطمينان ه9\%٪ } & \multirow{2}{*}{ سطح } & \multirow[t]{2}{*}{$\mathbf{t}$} & \multirow{2}{*}{ خطاى اسدارد } & \multirow[t]{2}{*}{ B } & \multirow[t]{2}{*}{ يارامتر } \\
\hline & حد بالا & حد يايين & & & & & \\
\hline$\cdot / v \cdot \Delta$ & $Q V / \Delta F q$ & $91 / . r r$ &.$/ \cdot 1$ & $9 / \% q \Delta$ & N/YVA & W/WVG & عرض از مبدأ \\
\hline
\end{tabular}




\begin{tabular}{|c|c|c|c|c|c|c|c|}
\hline$\cdot / 4 \cdot 9$ & . /Faf & $\cdot / r \mid \cdot$ &.$/ \cdot 1$ & $\Delta / \cdot r q$ & $\cdot / \cdot v \cdot$ & $\cdot r \Delta r$ & يِش آزمون \\
\hline - / FrF & $I V / F \Delta$. & $V / 99 V$ &.$/ \cdot 1$ & $\Delta / Y Y F$ & $r / F \cdot V$ & $\mid r / \Delta V R$ & كروه آزمايش \\
\hline
\end{tabular}

تاثر توانبخشى شناختى بر تنظيم هيجانى بين V/V· برآورد يارامتر نشان مىدهد كه اندازه اثر درمان IV/FD توانبخشى شناختى در بهبود تنظيم هيجانى در سطح معنى Pار است. برآورد نشان مىدهد اندازه

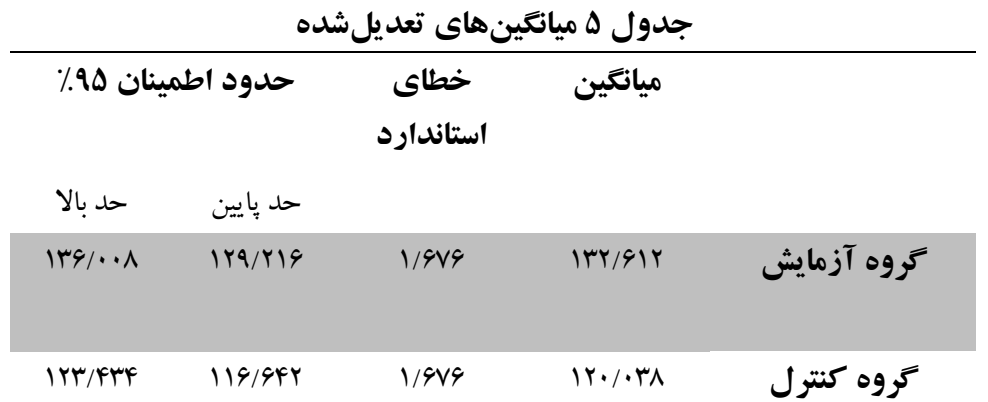

نيا و همكاران (Faf) كزارش كردند كه درمان شناختى رفتارى و درمان حضور ذهن تأثير معنىدار در

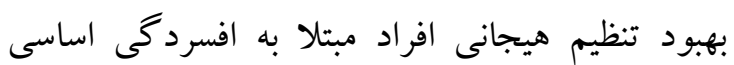

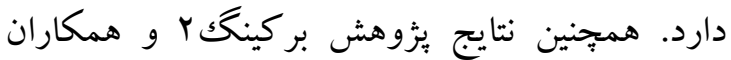
(Y) نشان داد اصلاح راهبردهاى ناساز كارانه تنظيم شناختى هيجان مىتواند علائم اختلال افسردگى را كاهش دهد. نتايج يُوهش با يافتهاى يُزوهش عالم

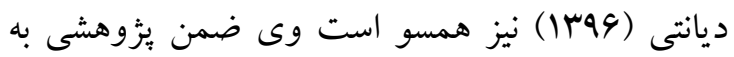
اين نتيجه رسيد كه آموزش شناخت درمانى مبتنى بر ذهن آكاهى بر كاهش راهبردهاى منفى تنظيم شناختى رسئ

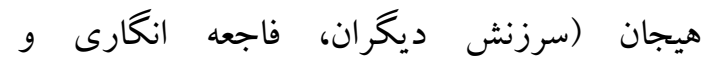
نشخوارگرى) در مبتلايان به اختلال وسواسى -جبرى

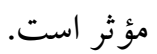
براى درك تأثير كذارى توانبخشى شناختى بر تنظيم هيجانى ابتدا بايد ماهيت اختلال بررسىشده را مورد توجه قرار داد. اصولاً افراد افسرده در برخورد با شرايط ناگوار، از راهبردهاى هيجانى متفاوتى استفاده مى كنند.
ميانگين تعديلشده تنظيم هيجانى گروه آزمايش |

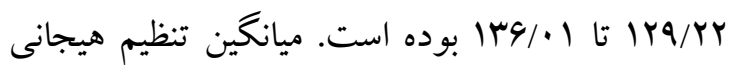

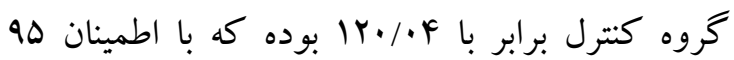

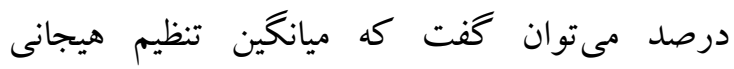

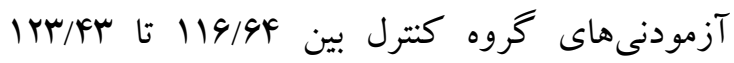

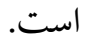
بزوهش حاضر با هدف تعيين تأثير آموزش توانبخشى شناختى بر ارتقاء تنظيم هيجانى زنان مبتلا به افسردگى بـى يس از زايمان انجام شد. يافتها نشاندهنده تأثير معنىدار توانبخشى شناختى باعث بر تنظيم هيجانى بود. اين يافته با يافتهاى بيزوهشهاى مردانى و

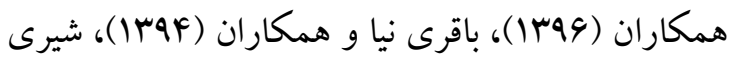

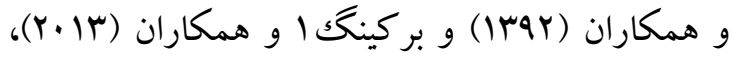

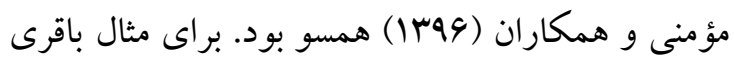


(نريمانى، •وبا ) كه اين موارد در اين بثزوهش از طريق يكيج آموزش توانبخشى شناختى به آزمودنى هاى كروه مداخله آموزش داده شد. شواهد نشان مى نىهند كه تنظيم هيجانى در كاهش نشانهاى افسردگى با مرون تغيير فر آيندهاى هيجانى و شناختى افراد اثر كذار است دئ

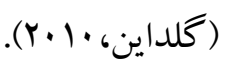

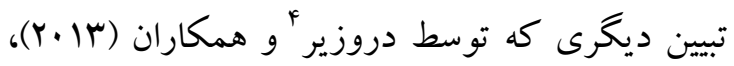

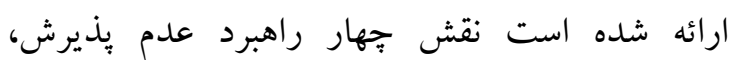
نكرانى، نشخوار فكرى و ارزيابى مجدد در رابطه بين تنظيم هيجانى با افسردگى است. با استناد به نظريه دروزير و همكاران، نقش تنظيم هيجانى در رابطه مورد يثزوهش ممكن است بهواسطه فر آيند ارزيابى مجدد باشد. ارزيابى مجدد شامل جارجوب پبندى يا تنظيم مجدد محرككهاى هيجانى فراخوانده شده به شيوهاى است كه اثر آن تجربه يا محركك اصلاح شود و يا به كونه اى اثر مخرب آن محرك هيجانى تغيير داده شود

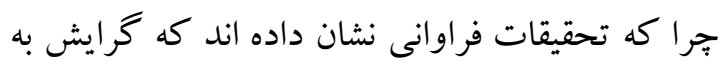
استفاده از اين راهبرد تنظيم هيجانى با سطوح كمتر

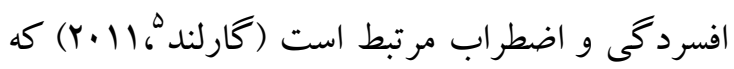
يكى از اهداف و رئوس برنامه آموزشى توانبخشى

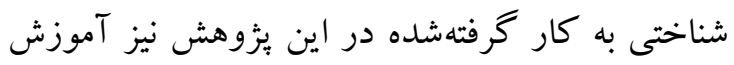

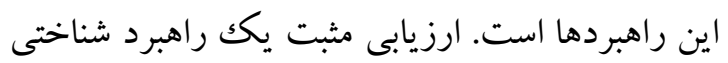
تنظيم هيجان است كه شامل تغيير روشهاى فكرى إي، به منظور كاهش فشارهاى هيجانى، در موقعيت بالقوه

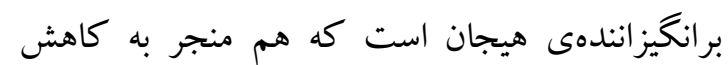
رفتارهاى بيانگر و هم تجربه هائه هاى منفى هيجانى

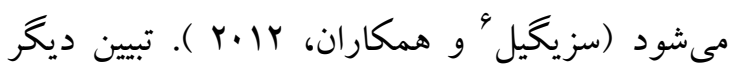

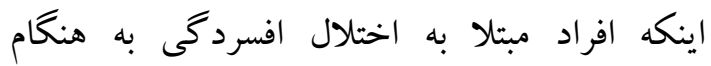
مواجهشدن با رويدادهاى ناخوشايند زندگى كه منجر إنى به يديدآيى هيجانهاى ناخوشايند در افراد مىشود
شواهد يثزوهشى نشان مىدهند كه افسردگى نهتنها بهوسيله تجربهى هيجانى ناهنجار شناخته مى شود (مثلاً عاطفهى مثبت پايين و عاطفهى منفى بالا) بلكه

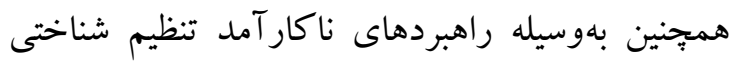
هيجان نيز مشخص مىشود .در نمونهاى بالينى استفاده بيشتر از نشخوار فكرى در باسخ به هيجانات

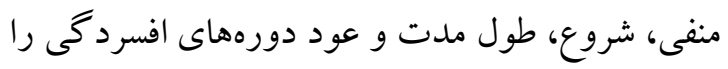

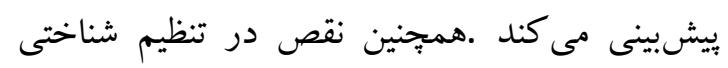

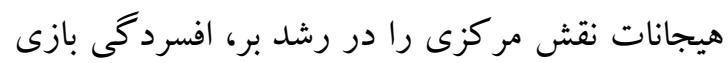

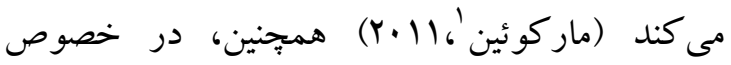
اينكه اختلال افسردگى با تنظيم هيجانى ارتباط دارد

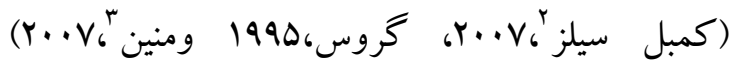
فرض بر اين است كه اكر افراد قادر به مديريت مؤثر باسخ هاى هيجانى در برابر وقايع روزمره نباشند يا دورههاى شديد و طولانى مدت آشفتكى را تجريه نمايند، ممكن است افسردگى قابل تشخيص را بروز مدول

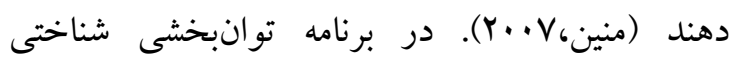
بخشى از تكاليف آموزشى مبتنى است بر ابعاد مختلف

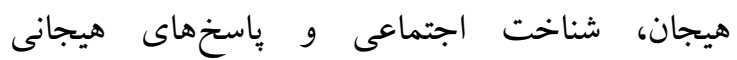
(نجاتى، بهr|) بنابراين بهبود تنظيم توانايى شناخت هيجانات، كنترل آن و بِاسخهاى هيجانى متناسب نقشى مهم در درمان افسردگى دارد به طورى كه بعضى از متخصصين تنظيم هيجانى را عامل اصلى تأثير كذارى

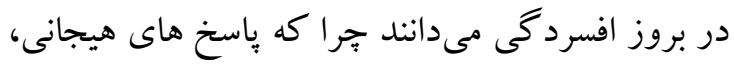
اطلاعات مهمى درباره تجربه فرد در ارتباط با ديخران فراهم مى كنند با اين اطلاعات، انسانها ياد مى گيرند

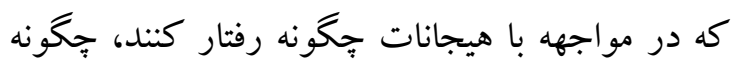
تجارب هيجانى را بهصورت كلامى بيان كنند، جه هوانه

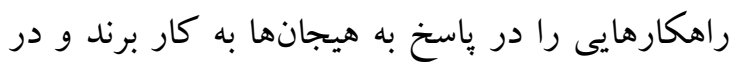

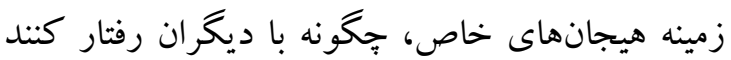




\section{نتيجه كيرى}

زنان مبتلا به افسردگى بس بـ از زايمان داراى مشكلات فراوانى بهويزه در زمينه تنظيم شناختى هيجان هستند، لذا نياز به برنامههايى براى ارتقاء تنظيم شناختى هيجان است كه آموزش توانبخشى شناختى به دليل ادغام يافتهاى علوم اعصاب شناختى و فناورى اطلاعات با تكيه بر اصل انعطاف يذيرى مغز و استفاده از بازى يكى از مهمترين اين برنامهها است. نتايج يثوهش حاضر نشان داد كه توانبخشى شناختى باعث بهبود تنظيم شناختى هيجان زنان مبتلا به افسردگى بِ از زايمان شد با توجه به تأثير آموزش شناختى بر كاركردهاى اجرايى، اين روش قابليت كاربرد در مراكز آموزشى و درمانى را دارد و جزء روشهاى درمانى مؤثر در ارتقاء تنظيم هيجان است بنابراين به مسئولان و برنامهريزان

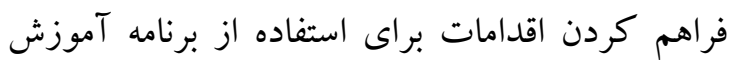
توانبخشى شناختى و به مشاوران و درمانگر ان استفاده از برنامه آموزش شناختى براى ارتقاء تنظيم شناختى

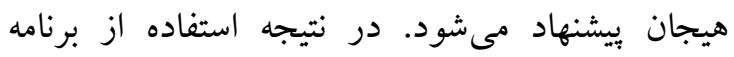
آموزش شناختى براى بهبود و اصلاح تنظيم هيجان بهويزه در زنان مبتلا به افسردگى يس از زايمان روش بهر

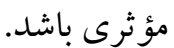
مهم ترين محدوديتهاى اين بثزوهش استفاده از روش بر بـ نمونه گيرى در دسترس و نداشتن فرصت كافى براى ائرون استفاده از مرحله ييخيرى دو يا سه ماهه جهت بررسى

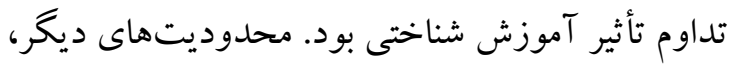

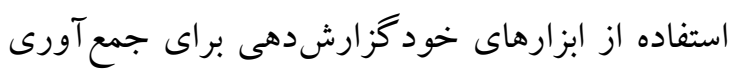
داده و محدود شدن نمونه يُزوهش به زنان مبتلا به افسردگى بس از زايمان شهر بوشهر بود. محدوديت

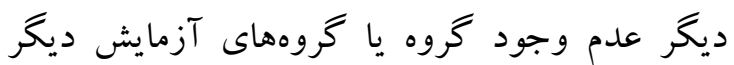
براى مقايسه نتايج آموزش روشهاى ديخر شناختى با آن بود؛ بنابر اين ييشنهاد مىشود در يُزوهش هاى آتى از

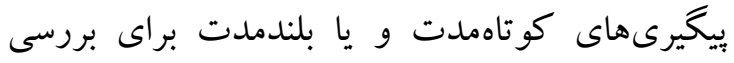

بهجاى الحاق معانى مثبت به آن رخداد منفى يا نسبى قلمداد كردن رويداد و انديشيدن درباره نحوه برخورد و مقابله با آن رويداد، به خودسرزنشى و مقصر قلمداد كردن خود مى يردازند و مدام درباره احساسات و

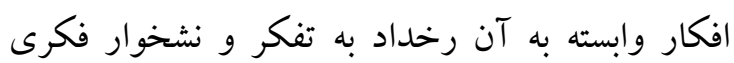

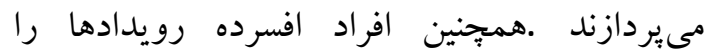
مصيبتبار و فاجعه آميز تلقى كرده و آنها را قطعى و حل نشدنى تلقى مى كنند .در نهايت، برخى از مؤلفان افسردگى را يكك اختلال ناشى از تنظيم هيجان مختل دانسته (جورمن'، ·1.1) و دوره هاى افسرده ساز را

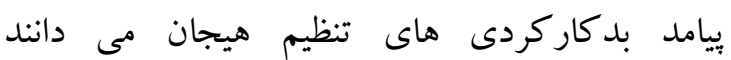

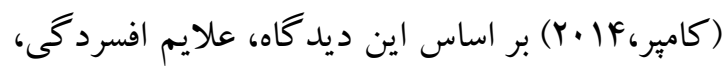
بيامد شكست افر اد در تنظيم ساز كارانه هيجان هايشان در نظر كرفته شده است. در تبينى ديخر بر مبناى نظر ديبيليوّ و همكاران (Y.IV) انسان نشان مىدهد كه آموزش عملكردهاى شناختى و مهارتهاى اساسى مىتواند تغييراتى در مقادير ماده خاكسترى و فعاليت سينايسى به وجود آورد. اين ترميم سينايسى براى بهبود يادگيرى و انجام فعاليتهاى شناختى مفيد است؛ بنابراين نكته تلويحى مهم براى برى بازتوانى اينكه تغييرات و دگرگ گونى در تجربه يكك شخص آسيبديده جريان معيوب شناختى را متأثر مىسازد و اين خود باعث بهبود آن مىشود. هم:جنين آموزش شناختى به شكل سلسله مراتبى و با درجات مختلف سختى به افراد ارائه مىشود. در واقع تسلط فرد بر انجام تكاليف و طى كردن سلسله مراتب سختى باعث بهبود و خودتنظيمى و عزت نفس آنها مى شود

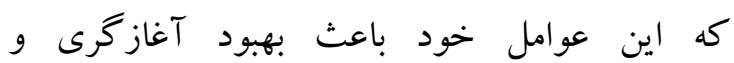
طرح يذيرى مىشوند.

\footnotetext{
1 Joormann
2 . Dibilio
} 
obsessive-compulsive disorder. Scientific and Research Joumal of Education and Evaluation, 40(2),6471. (in Persian).

Bagherinia H, Yemeni M, Javadi Elmi L, Nordadi T. (2015). Comparison of the Efficacy of Cognitive Behavior Therapy and Mindfulness-based Therapy in Improving Cognitive Emotion Regulation in Major Depressive Disorder. Armaghane Danesh, 20 (3) ,210-219. (in Persian).

Barlow, D.H., Allen, L.B., \& Choate, M.L.(2004). Toward a unified treatment for emotional disorders. Behavior Therapy, 35(2), 205230.

Berking, M., Ebert, D., Cuujpers, P., \& Hofmann, S.G. (2013). Emotion regulation skills training enhances the efficacy of inpatient cognitive behavioral therapy for major depressive disorder: a randomized controlled trial. Psychother Psychosom, 82(6), 234-245.

Burns A, O’Mahen H, Baxter H, et al.(2013). A pilot randomised controlled trial of cognitive behavioural therapy for antenatal depression. BMC psychiatry, 13(1), 33-45.

Campbell-Sills, L., \& Barlow, D. H. Incorporating emotion regulation (Ed.).(2007). Handbook of Emotion Regulation,(pp.). New York: Guilford, 542-559.

Compare A, Zarbo C, Shonin E, Van Gordon W, Marconi C. Emotional Regulation and Depression: A Potential Mediator between Heart and Mind.(2014). Cardiovasc Psychiatry Neurol,:32(43), 25-50.

Cox, J. L., Holden, J. M., \& Sagovsky, R.(1987). Detection of postnatal depression: development of the 10-item Edinburg Postnatal Depression Scale. British Joumal of Psychiatry, 150(21), 782-786.

Desrosiers, A., Vine, V., Klemanski, D.H., \& Nolen- Hoeksema, S.(2013). Mindfulness and emotion regulation in depression and anxiety: common and distinct mechanisms of action. Depression and anxiety, 30(7), 654-661.

Dibilio V, Nicoletti A, Mostile G, Portaro G, Luca A, et al.(2017). Computer-assisted cognitive rehabilitation on freezing of gait in Parkinson's disease: a pilot study. Neurosci Lett, 38(3), 41-65.

$$
\begin{aligned}
& \text { تداوم تأثير روش آموزش شناختى استفاده شود. بيشنهاد } \\
& \text { ديخر اينكه مىتوان روش آموزش شناختى را با ساير }
\end{aligned}
$$

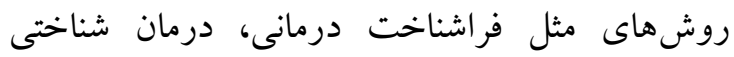

$$
\begin{aligned}
& \text { رفتارى، رفتاردرمانى ديالكتيكى، شناخت درمانى مبتنى رونى } \\
& \text { بر ذهن آكاهى، معنويت درمانى و طرحواره درمانى رصنى } \\
& \text { مقايسه كرد. بيشنهاد ديخر انجام اين بثزوهش در ساير } \\
& \text { كروهها است تا بتوان در تعميم نتايج و تأثير روش } \\
& \text { آموزش شناختى با دقت و اطمينان بيشترى بحث و و } \\
& \text { درباره آن قضاوت كرد. }
\end{aligned}
$$

$$
\begin{aligned}
& \text { سياسگزارى } \\
& \text { در اين مقاله هيج تعارض منافعى براى نويسندكان }
\end{aligned}
$$

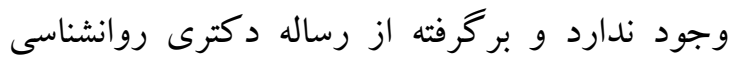

$$
\begin{aligned}
& \text { عمومى دانشگاه آزاد اسلامى واحد اهواز است كه با } \\
& \text { كد } \\
& \text { شركت كند كانى كه در انجام اين يُزوهش شركت } \\
& \text { داشتند، تشكر و قدردانى مىشود. }
\end{aligned}
$$

\section{References}

Abbasi M, Ayadi N, Pirani Z, Montazeri Z ( $\cdot 1 \mathrm{lV})$. The effect of cognitive rehabilitation on social well-being, quality of life and marital satisfaction of nurses. Iran $\mathrm{J}$ Health Educ Health Promot, 5(3),231-239. [in Persian].

Adouard F, Glangeaud-Freudenthal N, Golse B.(2005). Validation of the Edinburgh postnatal depression scale (EPDS) in asample of women with high-risk pregnancies in France. Arch Womens Ment Health, 8(2), 89-95.

Aldao, A., Nolen-Hoeksema, S., \& Schweizer, S.(2010). Emotion Regulation Strategies across Psychopathology: A Meta-analytic Teview. Clinical Psychology Review, 30(5), 217-237.

Alemdiantian F, Mohab N. (2017). The effect of cognitive therapy based on mind-awareness on reducing the negative strategies of cognitive emotion regulation in patients with 
Freitas CJ, Williams-Reade J, Distelberg B, Fox CA, Lister Z(2016).. Patemal depression during pregnancy and postpartum: An intemational Delphi study. J Affec Disord,202(4),128136.

Gagliardi C, Brenna V, Romaniello R, Amigoni F, Tavano A, et al.(2015). Cognitive rehabilitation in a child with Joubert syndrome: developmental trends and adaptive changes in a single case report. Res Dev Disabil, 47(5), 375-384.

Gaitan A, Garolera M, Cerulla N, Chico G, Rodriguez Querol M, Canela Soler J.(2013). Efficacy of an adjunctive computer based cognitive training programin amnestic mild cognitive impaiment and Alzheimer's disease: a single blind, randomized clinical trial. Int J Geriat Psychiatry, 28(1), 91-9.

Garland, E. L., Gaylord, S. A., \& Fredrickson, B. L.(2010). Positive reappraisal mediates the stress-reductive effects of mindfulness: An upward spiral process. Mindfulness, 2(1), 59-67.

Garnefski N, Kraaij V, Spinhoven P.(2001). Negative life events, cognitive emotion regulation and emotional problems. Pers Individ Dif , 30(8), 1311-27.

Garnefski, N., Kraaij, V., \& Spinhoven, P.(2001). Negative life events, cognitive emotion regulation and emotional problems. Personality and Individual Differences, 30(7), 1311-1327.

Goldin Evans M, Phillippi S, Gee RE. (2015). Examining the screening practices of physicians for postpartum depression: implications for improving health outcomes. Womens Health Issues, 25(6), 703-710.

Goldin, P. R., \& Gross, J. J. (2010). Effects of mindfulness-based stress reduction (MBSR) on emotion regulation in social anxiety disorder.Emotion, 10(6), 83-91.

Gratz KL, Roemer L.(2004). Multidimensional assessment of emotion regulation and dysregulation: development, factor structure, and initial validation of the difficulties in emotion regulation scale. Journal of Psychopathology and Behavioral Assessment,26(1), 41-54.

Gross JJ, Muñoz RF.(1995). Emotion regulation and mental health. Clinical Psychology: Science and Practice, 2(2),151-64.

Gross JJ. (2009). Emotion regulation: Conceptual and empirical foundations. In: Gross JJ. Editor. Handbook of emotion regulation. New York, NY: Guilford Press, 3-24.

Hasani, J.(2010). Reliability and validity of Persian of the cognitive emotion regulation questionnaire (CERQ). Joumal of clinical psychology, 24(5), 139-152. (in Persian).

Hawes K, McGowan E, O'Donnell M, Tucker R, Vohr B.(2016). Social emotional factors increase risk of postpartum depression in mothers of preterm infants. J Pediat., 179(8), 61-67.

Joormann J, Gotlib IH. (2010). Emotion regulation in depression: relation to cognitive inhibition. CognEmot, 24(2):281-98.

Kafetsios, K., Athanasiadou, M., \& Dimou, N.(2013). Leaders and subordinates attachment orientations, emotion regulation capabilities and affect at work: A multilevel analysis. The Leadership Quarterly,20(5), 119-131.

Kring AM, Werner KH. Emotion regulation and psychopathology.(2004). In: Philippot P, Feldman RS. Editors. The regulation of emotion. Abingdon, UK: Taylor \& Francis, 359-85.

Lockwood C.(2017). Cognitive rehabilitation for memory deficits after stroke: a Cochrane review summary. Int J Nurs Stud., 76(6),131-132.

Mao HJ, Li HJ, Chiu H, Chan WC, Chen SL.(2012). Effectiveness of Antenatal Emotional Self- Management Training Program in Prevention of Postnatal Depression in Chinese Women. Perspect Psychiatr Care, 48(4), 218-24.

Mardani S, Mehrabi Kushki HA. (2017). Depression prediction based on cognitive management strategies for excitement and marital satisfaction in women ]. Knowledge and Research in Applied Psychology,(2), 75-65. (in Persian).

Marroquín, B. (2011). Interpersonal emotion regulation as a mechanism of social support in depression. Clinical Psychology Review, 31(2), 1276-1290.

Marroquin, B.(2011). Interpersonal emotion regulation as a mechanism of social support 
in depression. Clinical Psychology Review, 31(8), 1276-1290.

Mazhari S, Nakhaee N. (2007). Validation of the Edinburgh postnatal depression scale in an Iranian sample. Arch Womens Ment Health , 10(6), 293-97. (in Persian).

Mennin, D., Holaway, R., Fresco, D., Moore, M., \& Heimberg, R. (2007). Delineating components of emotion and its dyes regulation in anxiety and mood psychopathology. Behavior Therapy, 38(9), 284-302.

Momeni F. (2016). Effectiveness of Emotion Regulation Training on Depression, Anxiety, and Emotional Dysregulation in Female University Students Living in Dormitories ]. J Res Behav Sci, 14(1), 64 71. (in Persian).

Narymani M, Aryapuran S, S.; Abolghasemi A, Ahadi B. (2011). Comparison of the Effectiveness of Mindfulness and Emotion Regulation Training on General Health of Veterans. jcps,2(14), 93-117. (in Persian).

Nejati V. (2014). Correlation of Risky Decision Making with Executive Function of Brain in adolescences ]. J Res Behave Sci, 11(4), 270-278. (in Persian).

O'Driscoll C, Laing J, Mason O. (2014). Cognitive emotion regulation strategies, alexithymia and dissociation in schizophrenia, a review and meta-analysis. Clin Psychol Rev, 34(6), 482-95.

Pepping M, Brunings J, Goldberg M.(2013). Cognition, cognitive dysfunction, and cognitive rehabilitation in multiple sclerosis. Phys Med Rehabil Clin N Am, 24(4),663672.

Roberts TA, Hansen S. (2017). Association of Hormonal Contraception with depression in the postpartum period. Contraception, 96(6), $446-452$.

Samani S, Sadeghi L. (2011). Psychometric properties of the cognitive emotion regulation questionnaire. J Psychol Methods Models, 1(1), 51-62. (in Persian).

Sharifi K, Sooky Z, Akbari H, Sharifi S M. (2008). Aseessment of the relationship between the method of delievery and postpartum depression]. Feyz, 12(1), 50-55. [in Persian]

Shiri E, Nejati V, PoueEtemad H. (2013).
Investigation of the Effectiveness of Cognitive Rehabilitation on Improving the Distinguishing of Emotional States in Children with High Functioning Autism Disorder]. JOEC, 13(3), 5-14. (in Persian).

Sloan, D.M., \& Kring, A.M.(2010). Intodaction and overview. Emotional regulation and psychopatology: A transdiagnostic approach to etiology and treatment (pp. 1-9). New York: Guilford Press, 1-9.

Szczygie, D., Buczny, J., \& Bazinska, R. (2012). Emotion regulation and emotional information processing: The moderating effect of emotional awareness. Personality and Individual Differences, 52(9), 433-437. 